\title{
Policy of Educational Budget Aceh Regency
}

\author{
Naidi Faisal, Nurhafni, Putri Murdiana and Zulhilmi \\ Faculty of Social and Political Sciences, Universitas Malikussaleh Lhokseumawe \\ City, Aceh, Indonesia
}

\section{Policy of Educational Budget Aceh Regency}

\begin{abstract}
Purpose - This research analyzes and describes the implementation of the North Aceh Regency education budget policy for improving the quality of education in relationship to the impact of the special autonomy budget.
\end{abstract}

Design/Methodology/Approach - This research uses qualitative research, descriptive-qualitative analysis methods, and qualitative explorative methods.

Findings - The results show that the implementation of the special autonomy education budget policy of North Aceh Regency to improve the education quality has not run optimally. The main obstacle is the inadequate human resource issue, including the leadership problems of regional heads who should prioritize the development. Based on field data of the actors involved in the formulation of the education quality improvement program in Aceh Utara District, especially the legislative branch (namely BAPPEDA), the education office and members of the Aceh legislative team, the post-conflict Aceh representation of the legislature at the provincial level, the DPRA and DPRK at the district level / in the field of political will produced. The resulting program does not focus on the pattern of improving the quality of education, the policy is more rhetorical, and the program implementation is often adapted to the wishes of political actors.

Research Limitations/Implications - Given the fundamental differences in the root causes of primary and secondary education in Aceh, further research is needed to determine whether similar results will be obtained in other parts of Aceh.

Originality/Value - Identifies factors that lead to the low quality of educators and the unequal distribution of teachers in the Aceh Regency.

Paper Type - Research paper

Keywords Policy, Budget Priority, Education Quality

All papers within this proceedings volume have been peer reviewed by the scientific committee of the Malikussaleh International Conference on Multidisciplinary Studies (MICoMS 2017).

\section{Introduction}

In a survey by the Political and Economic Risk Consultancy (PERC), the quality of education in Indonesia was ranked 12th out of 12 countries; Vietnam was ranked 11th. This level is due to the low quality of education reducing competitiveness, for which Indonesia ranks 37th out of 57 countries (The World Economic Forum Sweden Report, 2000). The Human Development Report (HDR), published in 2011 by the United Nations Development Programme (UNDP), reported that the Human Development Index Indonesia, which covers

(C) Naidi Faisal, Nurhafni, Putri Murdiana, Zulhilmi. Published in the Emerald Reach Proceedings Series. Published by Emerald Publishing Limited. This article is published under the Creative Commons Attribution (CC BY 4.0) licence. Anyone may reproduce, distribute, translate and create derivative works of this article (for both commercial and non-commercial purposes), subject to full attribution to the original publication and authors. The full terms of this licence may be seen at http://creativecommons.org/licences/by/4.0/legalcode
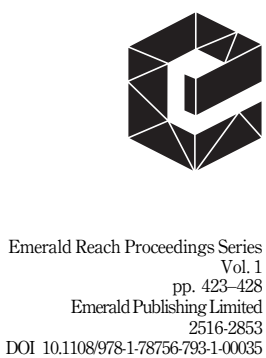
Proceedings of MICoMS 2017

424 the composition of the ranking of educational attainment, health, and earnings per head shows Indonesia as 124 out of 183 countries in the world.

For the province of Aceh in Indonesia, with its authority in special autonomy, education is full of problems. Compared with the education levels in 33 other provinces in Indonesia, the indicators of education rates for the Acehnese, such as gross enrollment rates (APK), literacy rates $(\mathrm{AMH})$, average school duration (ARLS), and net enrollment rates (APM) are better or above the national average, but the quality of Aceh's education is still very alarming (Majid, 2014). Political policy is crucial to the process of educational development in Indonesia. The lack of quality education in Indonesia is pointed out by some experts to be caused by the lack of an education budget (Nanang Fattah, 2006).

The province of Aceh received the largest number of education development fund in Indonesia through special autonomy sources: Rp 11.9 trillion in 2010 and $\mathrm{Rp} 9.6$ trillion in 2011, with a minimum allocation of $20 \%$ from APBA to advance education. The education budget has not been able to be accompanied by improved quality of education. Aceh's Human Development Index (HDI) fell from 17th place in 2009 to 27th in 2010. One of the education variables is the weak ability of teachers to master learning materials, as well as the uneven distribution of teachers between regions in Aceh. According to Ronald Edmonds $(1979,1982)$ the essential characteristics of effective schools are: 1) Strong leadership by the principal 2) High expectations by the teacher for student achievement, 3) An emphasis on basic skills; 4) An orderly environment; 5) Frequent, systematic evaluations of the student.

The policy pattern taken by the government in budget politics in education has not yet touched on the building of the human resource capacity. Where it is seen from the education fund for Aceh is very abundant, but still get the "red" card form the Indonesia government. Recorded, from 56,981 participants, as many as 785 students (1.38\%) Senior High School/ equivalent stated failed at National Examination (UN) 2013/2014 (Aceh Education office, 2014). Based on the empirical data, the Aceh government prioritizes the physical development of education rather than the increased competence of educators and learners; therefore, it makes the education quality inadequate. Physical development of education is not balanced with the increase in competitive capability; therefore, Aceh has relatively low levels of education. The priority of Aceh's education sector is still concerned with infrastructure development but ignores education quality development (Safriansyah, 2013). This political policy of the budget should naturally increase the educational capacity. The government's attention to education infrastructure has been great, so the physical facilitation of schools in Aceh is sufficient but the quality of its educators in strengthening human resources is lacking.

Indicators of the education level of most districts and municipalities in Aceh are quite good, but the quality is still tentative. Aceh's educational quality is ranked 25th out of 34 provinces in Indonesia, whereas the funds allocated for education sector are the third largest in Indonesia. The development of the education sector has been unevenly distributed among districts and cities in Aceh. The low level of education in some districts and municipalities in Aceh, especially in the newly divided districts, has caused poverty in the region to be high, exceeding 20\% (exceeding the national poverty rate 14.44\%. Mabri (2014: 34). Look at the readiness and paradigm of Aceh's local government for improving the education quality and not at the final achieved outcomes The research sites in the District of North Aceh (Lhokseumawe and Bireuen District) focused on the policy of district and city governments in improving the education quality in the region, factors causing the low quality of educators, and the unequal distribution of teachers in accordance with the provisions stipulated in the Law of Aceh No. 11 of 2006 and Qanun No. 5 of 2008 on the Implementation of Education. 
According to Dunn (1994), several steps or processes exist for conducting public policy analysis. Therefore, the first step of public policy analysis is monitoring and evaluation. In the context of special autonomy, according to Dunn's theory, is to start from the policy problems section. The problem in the special autonomy policy is the special autonomy policy of Aceh for education has been disbursed funds so large, but not yet able to improve the quality of education. Second, expected policy outcomes. Third, the policy alternatives will then be analyzed using Cost-Benefit Analysis to determine the policy to solve the existing problems as the preferred policy.

Master plan of education, educational regulation, education policy (policy of education): These terms imply a different content and scope of meaning. According to Arif Rohman (2009: 107-108). Education policy is a part of state or public policy in general. Education policy is a public policy that regulates specific regulations relating to the absorption of resources, allocation and distribution of sources, as well as the regulation of behavior in education. Education policy (educational policy) is a decision in the form of guidelines acting both simple and complex, both general and special, both detailed and loosely formulated through the political process for a certain direction of action, programs, and plans in carrying out education.

\section{Research methods}

The type of research used in this study is qualitative, in order to produce descriptive data analysis in the form of words written or spoken of the people and behavior observed, Moleong J Lexy (2004: 4). This research using descriptive-qualitative analysis methods, as well as qualitative explorative. This approach is used to analyze budget politics in the implementation of the special autonomy fund policy to improve the education quality, as well as inhibiting and supporting factors such as available resources, communication among stakeholders, implementation attitude towards programs and environmental conditions concerning social, economic and political conditions. Based on the facts by suggesting social phenomena in the field in full according to the aspects studied. The design of this study is the implementation evaluation study, due to the improvement of the quality of education through special autonomy fund, is a study of programs that are still running in improving the quality of education, it looks at the readiness and paradigm of local government in the process of organizing the improvement of education quality and not on the final result that has been achieved. The research location in North Aceh District is focused on the district government's policy of improving the quality of education in the region, identifying factors that lead to low quality of educators and the unequal distribution of teachers in accordance with the provisions stipulated in Aceh Law No. 11 Year 2006 and Qanun No. 5 of 2008 on the Implementation of Education.

\section{Discussion}

Results and Discussion Implementation of special autonomy policy in supporting the improvement of education quality has not run optimally. The main constraints are the inadequate human resources, including the leadership problems of the regional heads who should prioritize the development of not only infrastructure but also the quality of educators and education personnel. The highest allocation in the use of special autonomy fund for education in North Aceh is the largest allocation used in compulsory education program 9 years and secondary education. Allocations for both programs absorb 70 percent of the allocation of education, and there are also allocations for education and development programs of higher education and the quality and quantity of education personnel (11.3\%), early childhood education $(6.7 \%)$, education $(5.1 \%)$, while other programs received relatively 
Proceedings of MICoMS 2017 small allocations, namely sports and youth coaching $(2.2 \%)$, educational quality development (1.9\%), non-formal education (1.6\%) and library (1.1\%).

However, in every formulation of policies in Aceh Utara District, the actors involved in the formulation of education quality improvement programs, especially the legislative parties namely BAPPEDA, education service and members of the Acehnese legislative team, post-Aceh peace legislative representation both at provincial level (DPRA) and DPRK/ Weak city in the field of political will produced, so that the resulting program does not focus on the pattern of improving the quality of education, the policy is more rhetorical, program implementation is often adapted to the wishes of political actors, many programs are run on budget-oriented. Issues of interest at the executive level of the Governor and representatives and Regents / Mayors, regional secretaries, Heads in each SKPA and SKPD are filled with political nuances, officials are recommendations of legislatures that can be interfered by political power. So that the relationship of actors who formed more to the interests of power. Therefore, to spur North Aceh towards the advancement of education required a serious effort from the political actors in power.

Human Resource Improvement Program in improving the quality of education in North Aceh District. The program for improving the professionalism of educators and educational staff of the program being implemented is a compulsory education program of nine years of basic education in the composition of the program implementation there is a quality improvement program of educators and educational staff conducted with teacher training programs and this spent a budget of approximately $1 \mathrm{M}$, but the follow-up from teacher training, internship teachers, sending teachers abroad to continue higher levels of constraints will be the number of educators in Aceh Utara District is too much that is about 12,810 people this causes the implementation cannot be completed until 2017 this is constrained implementation of quality improvement programs educators and educational personnel lie in a limited budget. The number of teachers in the District of North Aceh requires thousands of stages in the implementation of training and that cannot be solved in the annual budget.

Infrastructure Development Program the budget allocation of education offices for improving the quality of educators and educational staff is still minimal. $30 \%$ is used to improve the quality of teachers, by means of training and $70 \%$ for the development and rehabilitation of educational infrastructure, for 2016 there are several innovation programs to improve the quality of education in Aceh Utara, such as training and training for educators and education personnel, as a whole budget amounting to Rp. 4,948,750,000, or 88 percent of the total special autonomy fund at the North Aceh Education and Culture Office. Funds for education in the regions have come from many sources, physically the current budget priorities are still devoted to infrastructure development as a contributing factor in the development of education.

Special autonomy funds in 2008 to 2011 are still managed by the province and in 2012 to 2013 still refer to the rule of Governor Regulation no. 79 of 2013 and special autonomy funds only implemented in districts in 2014, 2008 to 2013, the proposed program is determined by provincial districts to receive benefits only from those programs, by 2014 the special autonomy fund will be managed by districts/ municipalities, in the realization of the budget in 2014 until 2016 districts can manage the budget in accordance with the needs in each area of the implementation of the program first verified and already meet the administrative requirements with complete documentation then the proposal activities can be approved, but by 2018 will be re-managed the province.

Follow-up steps that need to be done is to improve the quality of educators and education personnel improve the quality, competence and professionalism both in public and private 
education units, improve reading culture and develop libraries to create learning communities, improve research and development of education as the basis of policy, and educational development activities, developing management of education services, enhancing the capacity of central and local education management institutions, promoting the application of transparency, accountability, participatory and democratization principles, and increasing community participation in educational development. In 2016 the quality improvement program of educators and educational staff has increased in the allocation of budget in 2015 total budget of quality improvement of educator and educational staff Rp. 653.180.000. While in 2016 increased to Rp. 4.948.750.000. The number of teachers in Aceh Utara District reaches 12,810, but educators and education personnel who attend the new training of 820 people. Constraints experienced in the realization of quality improvement programs educators and education personnel due to limited budget provided.

Education policy is directed to the needs of learners and the formation of organic intellectuals who become agents of renewal in the improvement of human resources for the realization of the development of quality education. A good education policy that can take into account the ability of the field, therefore needs to be considered the ability of educational personnel, the availability of funds, the implementation of a gradual and supported by the ability of human resources who master and able to apply all educational development programs. The educational problem faced by the education and culture office of North Aceh Regency is the lack of budget for improving the quality of education so that the impact on the low quality of education at every level and educational unit. Despite various efforts to improve the quality of national education such as national and local curricula, improving teacher competence through the procurement of books and instructional tools, procurement and improvement of facilities and infrastructure and improvement of school management quality. Nevertheless, education quality indicators have not shown any significant improvement.

\section{Conclusion}

Education problems faced by the education and culture office of North Aceh Regency is the lack of budget for improving the quality of education so that the impact on the low quality of education at every level and educational unit. Implementation of special autonomy policy in supporting the improvement of education quality has not run optimally. The main constraints are the lack of human resources, including the leadership problems of the regional heads who should prioritize the development not only the infrastructure but also the quality of educators and education personnel. The need for seriousness in the formulation of policies in Aceh Utara district, where the actors involved in the formulation of education quality improvement programs, especially the legislative namely BAPPEDA, education offices and members of the Aceh legislative team, both at the provincial level $D P R A$ and $D P R K$ at the Regency / focus on improving the quality of education.

\section{References}

Dunn, William, (1994), Public Policy Analysis: An Introduction. New Jersey: Prentice, Hall.

Hoy, Wayne K. (2005), Educational Administration. Toronto: McGraw Hill, page 97.

MSA Majid. (2014), Analisis Tingkat Pendidikan dan kemiskinan di Aceh, Jurnal Pencerahan, Volume 8, no 1.

Nanang, Fattah. (2006), Ekonomi dan Pembiayaan Pendidikan. Bandung: Rosda Karya, page 154.

Rohman, A (2009). Memahami pendidikan dan ilmu pendidikan. Yogyakarta: balai pustaka. 
Proceedings of Safriansyah, R., Masyrafah, H., Putra, T. T., and Suhand, R. (2013). Analisis Belanja Publik Aceh tahun MICoMS 2017 2013.

The World Economic Forum Sweden Report. (2000), Swedia.

Winarno, Budi. (2001), Kebijakan Publik: Teori \& Proses

United Nations Development Programme (UNDP), (2011), Human Development Report (HDR),2011. http://hdr.undp.org/en/media/HDR_2011_EN_Table2.pdf. Diunduh, 12 Juni 2012. Undang-Undang Nomor 32 Tahun 2004 tentang Pemerintah Daerah.

Undang-Undang Nomor 11 Tahun 2006 tentang Pemerintahan Aceh.

Qanun Nomor 6 Tahun 2016 tentang pembentukan dan susunan perangkat Kabupaten Aceh Utara.

\section{Corresponding author}

Putri Murdiana can be contacted at putrimurdiana@unimal.ac.id 